\title{
Analisis model pembelajaran ARIAS dalam seting berbagai tipe kolaboratif bagi peningkatan motivasi mahasiswa dalam pembelajaran MBS di PGSD FIP UNIMED
}

\author{
Efendi Manalu a, 1*, Ease Arent ${ }^{\text {b, } 2}$ \\ a,b. Universitas Negeri Medan, Medan, Indonesia \\ ${ }^{1}$ e.manalu11@gmail.com,*; ${ }^{2}$ easearent4@gmail.com \\ *korespondensi penulis \\ Informasi artikel ABSTRAK \\ Kata kunci: $\quad$ Tujuan penelitian ini adalah untuk mengetahui: (1) motivasi belajar sebelum dan setelah \\ Model diterapkan model ARIAS dalam setting kolaboratif tipe: TS-TS, Think Pair Share (TPS), Pair \\ pembelajaran Check (PC), dan Cooperative Script (CS) dalam pembelajaran. (2) implementasi model \\ ARIAS, $\quad$ ARIAS dalam seting kolaboratif tipe: TS-TS, Think Pair Share (TPS), Pair Check (PC), dan \\ Pendekatan Cooperative Script (CS) dalam pembelajaran, memberi pengaruh yang berlainan terhadap \\ Kolaboratif, $\quad$ peningkatan motivasi mahasiswa dalam pembelajaran perencanaan pengajaran PGSD FIP. \\ Motivasi belajar, Populasi dalam penelitian ini adalah semua Mahasiswa PGSD semester VI sebanyak 7 \\ Perilaku belajar $\quad$ rombongan belajar. Dari teknik samplingnya diambil kelas A Reg dan C Eks dan menjadi unit \\ sampel sebanyak 60 orang. Mahasiswa regular maupun ekstensi adalah sama-sama \\ menunjukkan peningkatan motivasi belajar atas model ARIAS melalui pembelajaran \\ kolaboratif tipe TS-TS, TPS, PC, dan CS yang di aktualisasi dalam melakukan aktivitas \\ belajar dalam mata kuliah perencanaan pembelajaran. Akan tetapi intensitasnya dalam \\ perilaku belajar berbeda yaitu lebih aktif mahasiswa regular dibandingkan mahasiswa \\ ekstensi dalam pembelajaran perencanaan pengajaran.

Keywords:
Arias model,
Collaborative
approach,
Learning
motivation,
Learning attitude \\ ABSTRACT \\ The purpose of this study was to determine: (1) motivation to learn before and after the ARIAS \\ model was applied in collaborative types: TS-TS, Think Pair Share (TPS), Pair Check (PC), \\ and Cooperative Script (CS) learning. (2) the implementation of the ARIAS model in type \\ collaborative settings: TS-TS, Think Pair Share (TPS), Pair Check (PC), and Cooperative \\ Script (CS) in learning, give a different influence on increasing student motivation in PGSD \\ teaching planning learning FIP. The population in this study were all sixth semester PGSD \\ students with 7 study groups. From the sampling technique, it was taken class A Reg and C \\ Ex and became a sample unit of 60 people. Regular and extension students are both showing \\ an increase in learning motivation over the ARIAS model through collaborative learning types \\ TS-TS, TPS, PC, and CS that are actualized in conducting learning activities in the course of \\ learning planning. However, the intensity in learning behavior is different, it more active \\ regular students than extension students in teaching planning learning.
}

\section{Copyright @ 2018 Efendi Manalu dan Ease Arent. All Right Reserved}

\section{PENDAHULUAN}

Dalam Undang-Undang Sistem Pendidikan Nasional Nomor 20 tahun 2003 dikatakan bahwa pembelajaran adalah proses interaksi peserta didik dengan pendidik dan sumber belajar pada suatu lingkungan belajar. Menurut

Corey (Sagala, 2003), pembelajaran merupakan

suatu proses dimana lingkungan seseorang secara sengaja dikelola untuk memungkinkan perubahan tingkah laku bagi peserta didiknya. 
Untuk itu menurut Rahman (2014), proses pembelajaran harus diawali dengan persiapan, kemudian penyampaian, latihan dan penampilan hasil. Sementara kegiatan mengajar di dalam pembelajaran itu menurut Burton (Sagala, 2003), adalah upaya memberikan stimulus, bimbingan, pengarahan dan dorongan kepada peserta siswa. Sedangkan kegiatan belajar siswa menurut Slameto (2003) adalah suatu proses usaha yang dilakukan siswa untuk memperoleh perubahan tingkah laku sebagai hasil pengalaman sendiri melalui interaksinya dengan lingkungan yang ada. Unsur utama dalam belajar oleh Rahman (2014) meliputi: individu sebagai peserta didik, kebutuhan sebagai sumber pendorong, situasi belajar yang memberi kemungkinan terjadinya kegiatan belajar, yang menunjuk pada perubahan tingkah laku.

Kesuksesan pembelajaran yang demikian menimbulkan perubahan tingkah laku bagi mahasiswa dengan mengisyaratkan adanya motivasi untuk melakukan tindakan tertentu. Sebab Purwanto (1997) berkata motivasi adalah merupakan syarat mutlak untuk belajar. Oleh sebab itu menurut Sumiati dan Asra (2013:59), "motivasi belajar adalah sesuatu yang mendorong siswa untuk berperilaku yang langsung menyebabkan munculnya perilaku dalam belajar. Lebih lanjut Sagala (2003) berkata motivasi seseorang akan menimbulkan faktor tertentu di dalam organisme yang membangkitkan, mengelola, mempertahankan dan menyalurkan tingkah laku menuju sasaran tertentu. Sehubungan dengan itulah, maka Rahman (2014) berkata: dalam proses pembelajaran harus ada hal yang dapat dijadikan sebagai motivasi atau dorongan yang timbul pada diri seseorang secara sadar atau tidak sadar untuk melakukan tindakan bagi mencapai tujuan pembelajaran. Sardiman (2014) berkata dalam kegiatan belajar motivasi adalah keseluruhan daya penggerak di dalam diri siswa yang menimbulkan kegiatan belajar, menjamin kelangsungan kegiatan belajar, dan memberi arah pada kegiatan belajar dan dapat menjamin pencapaian tujuan. Selanjutnya, Dimyati dan Mudjiono (2009) mengatakan motivasi belajar merupakan kekuatan mental yang mendorong terjadinya proses belajar; lemahnya motivasi atau tidak adanya motivasi belajar akan melemahkan kegiatan belajar selanjutnya mutu hasil belajar akan menjadi lemah. Demikian juga Sagala (2009) berkata: motivasi belajar merupakan penggerak yang menggugah seseorang untuk memulai dan melakukan kegiatan tertentu”. Jadi peranan motivasi tersebut adalah penumbuhan gairah, merasa senang dan semangat untuk belajar, siswa yang memiliki motivasi kuat akan mempunyai banyak energy untuk melakukan kegiatan belajar.” Makna motivasi ini sangat berkaitan erat dengan minat karena Bernard (Suhardiman, 2011) berkata bahwa "minat tidak timbul secara tiba-tiba/spontan melainkan timbul akibat partisipasi, pengalaman, 
kebiasaan, pada waktu belajar dan bekerja”. Artinya, motivasi akan terwujud dalam bentuk perilaku bila diikuti oleh minat atau keinginan tertentu.

Sementara Morgan (Sardiman, 2011) berkata bahwa "kebutuhan yang berhubungan dengan motivasi adalah: meliputi kebutuhan 1) untuk berbuat bagi suatu aktivitas tertentu, 2) untuk menyenangkan orang lain, 3) untuk mencapai hasil , kebutuhan mengatasi kesulitan dan, 4) untuk mewujudkan diri sendiri”. Sedangkan Maslow (Soemanto, 1983), mengatakan "motivasi seseorang mahasiswa dalam konteks pendidikan tidak mungkin berkembang bila kebutuhan yang dirasakan seseorang tidak terpenuhi”. Bahkan Saw (1979) berkata "kepuasan akan kebutuhan seseorang secara individu lebih penting dari pada tujuan nyata, seseorang yang terpenuhi kebutuhannya akan membantu dan mendukung pencapaian tujuan organisasi atau kelompok bahkan menjadi kontributor yang sangat berarti untuk meneruskan.

Uraian-uraian tersebut menunjukkan, bahwa motivasi belajar seseorang akan timbul dan atau meningkat adalah ketika desain pembelajaran dan proses pelaksanaannya dikondisikan sedemikian agar mengandung kebutuhan, harapan serta aspek kepribadian siswa secara holistic kelak dimanivestaikan dalam aktivitas belajar sesuai tujuan yang digariskan sehingga menimbulkan perubahan dalam diri siswa/ mahasiswa baik mental, intelektual, sosio-emosinal, motoric dan sikap secara menyeluruh

Bila dicermati kenyataan lapangan oleh peneliti sebagai salah seorang dosen FIP, tampaknya mahasiswa PGSD dalam proses perkuliahan masih banyak yang belum menyatakan aktivitas belajar atau perilaku belajar secara maksimal. Kalaupun dieksipresikan, diprediksi hanya karena takut sanksi dan bukan atas kesadarannya. Fenomenanya, kehadiran mahasiswa hanya seremonial semata, duduk di bangku, menulis bila dianjurkan, dan bahkan tidak jarang mahasiswa pulang tanpa ada catatan apapun, tugas pun jarang terkumpul sesuai waktu tagihan yang telah ditetapkan bersama, demikian juga minat belajarnya rendah. Selain itu, belum tampak keinginan menguasai materi secara intensif maupun ekstensif. Oleh karena itu pengalaman belajarnya masih tergolong rendah belum mengacu pada kaidah pembelajaran seorang mahasiswa Artinya proses perkuliahan yang dikondisikan oleh dosen masih belum mengandung kebutuhan atau minat dan juga harapan mahasiswa secara psikologis sehingga belum menjamin peningkatan motivasi belajarnya secara optimal. Fenomena tersebut tampak pada mahasiswa baik regular maupun ekstensi.

Secara teoretis, masalah kebutuhan atau keinginan yang mengacu pada motivasi belajar dapat ditelaah melalui model pembelajaran ARIAS. Oleh karena pembelajaran ARIAS 
menurut Sopah (2008) dalam kutipan Surahman (2014) adalah usaha pertama dalam kegiatan pembelajaran yaitu untuk menanamkan rasa yakin atau/percaya pada siswa, kegiatannya relevan dengan kehidupan siswa, berusaha menarik dan memelihara minat atau perhatian siswa, kemudian diadakan evaluasi dan menumbuhkan rasa bangga kepada siswa dengan memberikan penguatan. Komponennya menurut Fajaroh (2007) dalam kutipan Surahman (2014) sesuai akronimnya adalah: Assurance (menanamkan sikap kepercayaan diri pada siswa), Relevance (mengembangkan pengalaman sesuai kehidupan siswa), Interest (mengondisikan kegiatan pembelajaran sesuai minat siswa), Assesment (menanamkan sikap evaluasi diri maupun terhadap teman) dan Satisfaction (menyatakan kepuasan dan atau kebanggaan atas hasil yang dicapai.). Demikian halnya, jelas peningkatan motivasi belajar akan terjamin bila model pembelajaran yang dilaksanakan mengandung kebutuhan dan keinginan seseorang secara psikologis. Akhirnya proses pembelajaran pun produktif dan dinamis bagi pencapaian tujuan. secara efektif dan efisien.

Makna yang terkandung dalam konsep ARIAS tersebut dapat menjanjikan peningkatan motivasi belajar karena faktor Asurance, Relevansi, Interes, Assesment, dan Satisfaction audience, yang dikondisikan dalam proses pembelajaran secara simultan atau parsial dapat menggugah timbulnya dorongan atau keinginan untuk melakukan aktivitas belajar. Hubungannya Bandura (1977) dalam kutipan Muhibin Syah (2004) berkata motivasi belajar siswa/ mahasiswa dapat ditumbuhkan melalui pujian, hadiah atau nilai yang diberikan guru kepada siswa yang telah menunjukkan keberhasilan Sementara bagi mereka yang belum menunjukkan kinerja yang memuaskan perlu diyakinkan arti pentingnya penguasaan materi atau perilaku yang disajikan bagi mereka. karena, model ini menembus pada kebutuhan atau keinginan seseorang. Selanjutnya Suciati (2001) dalam kutipan Melfaetty (2011) berkata: motivasi belajar yang diekspresikan dalam perilaku belajar dan bekerja memiliki empat komponen, yakni: keberhasilan mencapai tujuan belajar sebagai akibat adanya kepuasan atas harapan (1) Perhatian (attention) yaitu perhatian siswa terhadap pelajaran karena dorongan ingin tahu; (2) relevansi yakni sikap memelihara perilaku belajar karena ada kesesuaian pelajaran dengan pemenuhan kebutuhan pribadinya, serta bermanfaat terhadap dirinya; (3) cofidence (percaya diri) yaitu perasaan mampu karena memiliki potensi untuk melakukan tugas sebagai syarat mencapai keberhasilan; dan (4) satisfaction (kepuasan).

Sedangkan implementasinya dalam kegiatan belajar menurut Dimyati (2002) dalam kutipan Melvayetty (2001) dapat dilihat dari minat, perhatian, dan keinginan kuat untuk ikut serta dalam proses belaja. dijelaskan bahwa 
motivasi belajar mahasiswa akan meningkat atau tumbuh serta terpelihara Dengan kata lain motivasi seseorang meningkat atau tumbuh dengan baik adalah ketika desain pembelajaran mengadung kebutuhan, harapan, minat dan atau keinginan mahasiswa. Di sisi lain proses pembelajarannya dikondisikan sedemikian rupa sehingga mampu memberikan kepuasan, reinforcement ataupun pengakuan atas keberadaan mahasiswa secara individual.

Pembelajaran ARIAS sebagai suatu model secara teknis harus diimplementasi dalam strategi tertentu. Sebab namanya model masih bersifat kerangka konseptual yang mendeskripsikan dan melukiskan prosedur yang sistematik dalam mengorganisasikan pengalaman belajar dan pembelajaran dan digunakan sebagai pedoman dalam melakukan kegiatan untuk mencapai tujuan belajar. Strategi pembelajaran yang mengintegrasikan model ARIAS dalam hal ini adalah dengan seting kolaboratif atau kooperatif learning pada tipe -tipe pembelajarannya. Menurut Huda (2014) pendekatan kolaborasi meliputi 10 tipe. Namun secara empirik belum dapat dijelaskan model ARIAS pada tipe mana yang paling produktif meningkatkan motivasi belajar seseorang. Mengingat keterbatasan peneliti dalam berbagai hal, peneliti membatasinya pada 4 tipe yakni tipe Tow Stay-Tow Stray (TS-TS);

Think Pire Sare (TPS), Pair Check (PC), dan Cooperative Script (CS).

Bertolak dari uraian tersebut, peneliti tertarik menelaah peningkatan motivasi mahasiswa atas model ARIAS dalam pembelajaran kolaboratif tipe Tow Stay-Tow Stray (TS-TS); Think Pire Sare (TPS), Pair Check (PC), dan Cooperative Script (CS) di PGSD. Sesuai dengan fenomena yang telah diuraikan terdahulu, maka penelitian ini konsentrasi pada pembelajaran mahasiswa reguler dan ekstensi pada mata kuliah Perencanaan Pengajaran (PP).

\section{METODE}

Penelitian ini dilaksanakan di Fakultas Ilmu Pendidkan (FIP) UNIMED. Waktu penelitian dimulai pada Mei hingga Nopember 2016 selama 7 bulan. Tindakannya dilakukan dengan dua siklus dan setiap siklus dilaksanakan selama 6 minggu peneliti menggunakan metode penelitian pengembangan kelak diimplementasikan dalam penelitian tindakan kelas.

Peneliti melakukan tindakan kelas dengan mengikuti prosedur PTK yang dikemukakan Kemmis dalam kutipan Dewi (2009) yakni: penyusunan rencana, tindakan kelas, observasi tindakan, refleksi. Desainnya digambar sebagai berikut: 


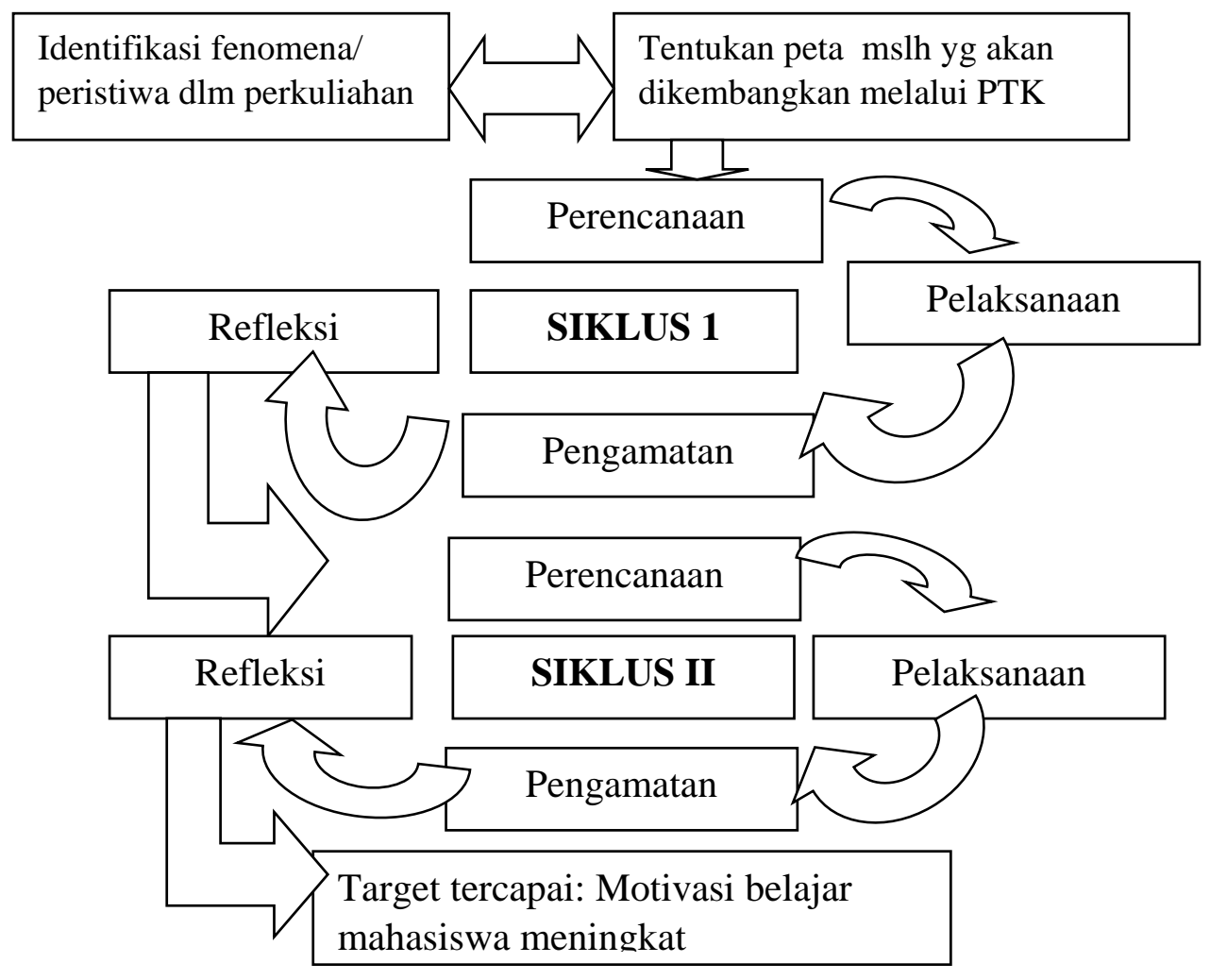

\section{HASIL DAN PEMBAHASAN}

Bertolak dari analisis data deskriptif mengenai pelaksanaan model ARIAS melalui pembelajaran kolaboratif tipe TS-TS, TPS, PC, CS dalam meningkatkan motivasi belajar mahasiswa. Proses pembelajaran mahasiswa Reguler maupun Ekstensi dengan model ARIAS dalam seting kolaboratif dengan tipe Tow Stay-Tow Stray, Think Pair Share, Pair Check, dan Cooperative Scripts secara deskriptif dari siklus I ke siklus II kedua factor tersebut sama-sama mengalami peningkatan . Hal ini dibuktikan bahwa pembelajaran pada kelas regular pada tipe : TS_TS pada siklus I kategori baik dengan nilai 2,82, setelah siklus II menjadi 3,37 dengan kategori sangat baik; tipe TPS pada siklus I memperoleh nilai 3,05 kategori baik setelah siklus II menjadi 3,53 kategori sangat baik ; tipe PC pada siklus I memperoleh nilai 2,80 kategori baik setelah siklus II menjadi 3,29; dengan kategori sangat baik dan tipe CS pada siklus I memperoleh nilai 2,68 dengan kategori baik setelah siklus II menjadi 3,17 dengan kategori baik. Sedangkan, nilai proses pembelajaran mahasiswa ekstensi secara deskriptif dari siklus I ke siklus II mengalami peningkatan. Hal ini dibuktikan dengan nilai masing-masing tipe TS_TS siklus I memperoleh nilai 2,67 kategori baik setelah siklus II menjadi 3,29 dengan kategori sangat baik; tipe TPS pada siklus I memperoleh nilai 
2,97 kategori baik setelah siklus II menjadi 3,33 kategori sangat baik; tipe PC pada siklus I memperoleh nilai 2,80 kategori baik setelah siklus II memperoleh nilai 3,16 kategori baik dan tipe CS pada siklus I memperoleh nilai 2,63 kategori baik dan setelah siklus II memperoleh nilai 3,11 kategori baik.

Dari interpretasi data tersebut, disimpulkan secara kuantitatifnya bahwa tipe TS_TS, TPS dan PC sama sama kategori sangat baik, dan tipe CS masih kategori baik. Dari semua tipe ini, tipe TPS menunjukkan peringkat yang tertinggi, dan tipe CS adalah tipe yang mendapat nilai paling rendah. Oleh karena secara kuantitatifnya nilai masing-masing tipe pembelajaran TS-TS, TPS, PC, dan CS yang ditemukan berbeda satu sama lainnya dalam meningkatkan motivasi belajar mahasiswa regular maupun ekstensi.

Selanjutnya nilai motivasi belajar mahasiswa regular maupun mahasiswa ekstensi mengalami peningkatan setelah tindakan dilakukan dalam pembelajaran perencanaan pengajaran. Hal ini dibuktikan bahwa rerata nilai motivasi mahasiswa regular atas model ARIAS dalam pembelajaran kolaboratif tipe TS-TS, TPS, PC, CS pada mata kuliah perencanaan pengajaran sebelum tindakan tergolong sedang dengan rerata nilai 2,10 setelah tindakan pada siklus I meningkat menjadi kategori baik dengan nilai 2,73, dan setelah tindakan pada siklus II meningkat lagi menjadi kategori sangat baik dengan nilai 3,31.
Demikian juga nilai motivasi belajar mahasiswa ekstensi, sebelum tindakan tergolong sedang dengan rerata nilai 2, 04, setelah tindakan pada siklus I meningkat menjadi kategori baik dengan nilai 2,60, dan setelah tindakan pada siklus II meningkat menjadi kategori sangat baik dengan nilai 3,28. Artinya, setelah siklus II motivasi belajar mahasiswa baik regular maupun ekstensi samasama meningkat dengan kategori sangat baik.

Selanjutnya hasil pengujian hipotesis penelitian yang berbunyi: Model ARIAS dalam pendekatan kolaboratif tipe TS-TS, TPS, PC, CS tidak memberi pengaruh yang berlainan terhadap peningkatan motivasi belajar mahasiswa regular dan mahasiswa ekstensi pada pembelajaran perencanaan pengajaran di PGSD FIP adalah berikut:

Hasil uji statistic $X_{r}^{2}$ pada kelas A Reguler membuktikan , $X_{r}^{2}$ hit 8,64 < nilai bel C 17,71 pada Db : 29 dan $\propto$ : 0,05. Dengan menolak H0. Dan menerima H1(hipotesis penelitian) dengan tingkat kepercayaan 95\%.

Demikian juga pada kelas C Ekstensi membuktikan, adalah $: X_{r}^{2}$ hit : 3,56< nilai $X_{r}^{2}$ tab 17,71 pada db 29 dan $\propto$ 0.05. dengan menolak H0. Dengan menerima H1 (hipotesis penelitian) dengan tingkat kepercayaan 95\%.

Kesimpulan statistiknya: bahwa Model ARIAS dalam pendekatan kolaboratif tipe TSTS, TPS, PC, CS memberi pengaruh yang sama (tidak memberi pengaruh yang berlainan) satu 
sama lain terhadap peningkatan motivasi belajar mahasiswa regular dan mahasiswa ekstensi pada pembelajaran perencanaan pengajaran di PGSD FIP.

Berangkat dari analisis deskriptif dan hasil uji statistic tersebut di atas, dijelaskan bahwa perbedaan deskriptif yang telah dikemukakan atas nilai model ARIAS dalam pembelajaran kolaboratif tipe TS-TS, TPS, PC, dan CS dalam peningkatan motivasi belajar mahasiswa pada perkuliahan perencanaan pengajaran secara statistic tidak punya arti (tidak signifikan). Oleh sebab itu, pembelajaran ARIAS dalam tipe tersebut sama kekuatannya untuk meningkatkan motivasi belajar mahasiswa. Dalam indikator: (1) adanya keinginan berhasil, (2) adanya dorongan dan kebutuhan dalam belajar (3) adanya harapan dan cita-cita;(4) ada penghargaan dalam belajar, (5) ada kegiatan yang menarik, dan (6) tercipta lingkungan belajar yang kondusif bagi pelaksanaan pembelajaran para mahasiswa. Manifestasinya dinyatakan dalam bentuk perilaku belajar: 1) tekun menghadapi tugas 2) ulet menghadapi kesulitan 3) menunjukkan minat, 4) lebih senang bekerja mandiri, 5) cepat bosan dengan tugas yang rutin 6) mempertahankan pendapat 7) tidak mudah melepaskan hal yang diyakininya 8) senang mencari dan memecahkan masalah/ soal-soal. 9) tidak mau menyerah tanpa berusaha, 10) sikap segera puas dengan apa yang telah dikuasai atau dipahami, dan 11) selalu senang berhadapan dengan masalah yang berkaitan dengan materi kuliah, dan sebagainya

Model ARIAS melalui pembelajaran kolaboratif tipe TS-TS, TPS, PC, da, CS telah terlaksana di kelas regular maupun ekstensi dengan baik. Implementasinya, pembelajaran kolaboratif telah dikondisikan dengan menunjukkan karakteristik: Assurance (menanamkan sikap kepercayaan diri pada siswa), Relevance (mengembangkan pengalaman sesuai kehidupan siswa), Interest (mengondisikan kegiatan pembelajaran sesuai minat siswa), Assessment (menanamkan sikap evaluasi diri maupun terhadap teman) dan Satisfaction (menyatakan kepuasan dan atau kebanggaan atas hasil yang dicapai.). Sehingga tercipta situasi dalam proses pembelajaran: (1) menerima teman yang lain dalam kelompok belajar, (2) membantu teman yang lain dalam kelompok belajar; (3) tegar menghadapi tantangan dan rintangan yang muncul dari topik pembahasan; (4) senang belajar dalam tim. Di pihak lain pembelajaran dikondisikan dosen agar memungkinkan :1) untuk saling yakin/ percaya diri antar mahasiswa sehingga saling menerima teman dalam kelompok belajar, 2) untuk menumbuhkan minat dan manfaat yang fungsional bagi mahasiswa, sehingga mampu menghadapi tantangan atau kesulitan dalam pembelajaran, 3) untuk saling melakukan penilaian diri sendiri, 4) untuk saling memiliki keinginan membantu yang lain dalam kelompok, serta 5) saling merasakan kepuasan 
yang menimbulkan kenyamanan, dan keamanan untuk bertahan menyelesaikan tugas dalam kelompok. Dengan kata lain, proses pembelajaran yang dilakukan relative dinamis, produktif dan efektif dalam mencapai tujuan yang telah digariskan. Secara simultan situasi dan kondisi yang demikian dapat meningkatkan motivasi belajar yang kuat dalam melakukan aktivitas belajar pada pembelajaran perencanaan pengajaran. Dengan demikian jelas, bahwa model ARIAS melalui pembelajaran kolaboratif tipe TS-TS, TPS, PC, dan CS semacam itu. sangat berpotensi untuk menjanjikan peningkatan motivasi belajar mahasiswa dalam proses pembelajaran yang dilakukannya. mencapai tujuan yang telah digariskan.

Data penelitian ini sejalan dengan konsep teori seperti yang dikemukakan oleh Bandura (1977) dalam kutipan Muhibin Syah (2004) berkata motivasi belajar siswa/ mahasiswa dapat ditumbuhkan melalui pujian, hadiah atau nilai yang diberikan guru kepada siswa yang telah menunjukkan keberhasilan. Sementara bagi mereka yang belum menunjukkan kinerja yang memuaskan perlu diyakinkan arti pentingnya penguasaan materi atau perilaku yang disajikan bagi mereka karena model ini menembus pada kebutuhan atau keinginan seseorang. Demikian juga Maslow (Soemanto, 1983), bahwa “motivasi seseorang siswa dalam konteks pendidikan tidak mungkin berkembang bila kebutuhan yang dirasakan seorang tidak terpenuhi. Bahkan Saw (1979) berkata "kepuasan seseorang secara individu lebih penting dari pada tujuan nyata”. Jika seseorang merasa tidak diberi kesempatan untuk menyelesaikan tugas, ketidak puasanya cukup berarti untuk merintangi pencapaian tujuan. Kemudian seseorang yang terpenuhi kebutuhannya akan membantu dan mendukung pencapaian tujuan organisasi atau kelompok bahkan menjadi kontributor yang sangat berarti untuk meneruskan kegiatan selanjutnya.

Selanjutnya Suciati (2001) dalam kutipan Melfaetty (2011) berkata “motivasi belajar yang diekspresikan dalam perilaku belajar memiliki empat komponen, yakni: keberhasilan mencapai tujuan belajar sebagai akibat adanya kepuasan atas harapan (1) perhatian, (2) relevansi, (3) confidence, dan (4) satisfaction.

Dari sisi pembelajaran khususnya teori behaviorisme dikatakan pembelajaran sebagai stimulus akan semakin baik untuk menghasilkan respons bila mendapat pengulangan. Hubungannya Rahman (2014) berkata: pembelajaran menekankan kegiatan belajar sebagai aktivitas yang menuntut siswa untuk mengungkapkan kembali pengetahuan yang telah dipelajari. Artinya, semakin sering dilakukan suatu pembelajaran akan semakin baik pelaksanaannya serta semakin potensial untuk menanamkan pengalaman belajar tertentu kepada peserta didiknya

Terakhir hasil uji beda statistik bagi pengujian hipotesis yang berbunyi: Model 
ARIAS dalam pendekatan kolaboratif tipe TSTS, TPS, PC, CS tidak memberi pengaruh yang berlainan terhadap motivasi belajar mahasiswa regular dan mahasiswa ekstensi pada pembelajaran perencanaan pengajaran di PGSD FIP.

Pengujian ini dimaksudkan untuk mengestimasi, apakah peningkatan motivasi yang dibuktikan uji beda $\mathrm{X}_{\mathrm{r}}^{2}$ terdahulu sama pada kelas regular dan ekstensi secara independen. Model ARIAS dengan pendekatan kolaboratif tipe TS-TS, TPS, PC, CS memberi pengaruh yang berlainan (berbeda) terhadap peningkatan motivasi belajar mahasiswa regular dengan mahasiswa ekstensi pada pembelajaran perencanaan pengajaran di PGSD. Bertolak dari hasil analisis deskriptif dan pengujian hipotesis tersebut, dijelaskan bahwa peningkatan motivasi belajar mahasiswa kelas A Reguler dengan kelas C Ekstensi berbeda Perbedaan yang demikian bukan karena implementasi model ARIAS dalam pendekatan kolaboratif itu sendiri. Diprediksi adalah akibat adanya perbedaan potensi atau kemampuan yang dimiliki oleh mahasiswa yakni kemampuan mahasiswa regular lebih tinggi dari pada potensi atau kemampuan mahasiswa ekstensi. Hubungannya, banyak para ahli psikologi berkata seperti Segne (Syarif. dkk, 2016) berkata bahwa "kemampuan intelektual seseorang sangat besar pengaruhnya terhadap perilaku (kognitif, sikap, motorik) dalam proses belajar yang dilakukan seseorang. Dalam teori konvergensi oleh Willeam Sterm (Syarif. dkk, 2016) ditegaskan bahwa proses perkembangan seseorang dalam aktualisasi dirinya sangat ditentukan oleh potensi (bawaan lahir) dan lingkungan pendidikannya. Faktor tersebut akan mengakibatkan sikap dan perilaku mahasiswa ekstensi dalam pembelajaran: (1) kurang keyakinan antar sesama untuk menerima teman dalam kelompok belajar,(2) kurangnya minat belajar dan manfaat yang fungsional bagi mahasiswa, (3) kurang kemampuan menghadapi tantangan atau kesulitan dalam pembelajaran, (4) kurang mampu melakukan penilaian diri sendiri yang menimbulkan kurang keinginan membantu yang lain dalam kelompok, serta, (5) kurang puas dengan pembelajaran yang mengakibatkan kurangnya kenyamanan dan keamanan untuk bertahan menyelesaikan tugas dalam kelompok. Sadar tidak sadar hal yang demikian, secara psikologis dapat mengakibatkan kurangnya dorongan atau motivasi bagi mahasiswa ekstensi dibandingkan pada mahasiswa kelas A reguler

Konsekuensinya, motivasi mahasiswa regular dalam pembelajaran, lebih tinggi dibandingkan mahasiswa ekstensi dalam hal: (1) keinginan berhasil, (2) dorongan dan kebutuhan dalam belajar yang berbeda (3) harapan dan cita-cita ;(4) penghargaan dalam belajar yang berbeda, (5) pengaturan kegiatan yang menarik, dan (6) pengondisian 
lingkungan belajar yang kondusif bagi dorongan ingin tahu; (2) relevansi yakni sikap pelaksanaan pembelajaran para mahasiswa. memelihara perilaku belajar karena ada Manifestasinya bahwa mahasiswa regular lebih kesesuaian pelajaran dengan pemenuhan optimal dan semangat dibandingkan mahasiswa kebutuhan pribadinya, serta bermanfaat ekstensi dalam perilaku belajar seperti: 1) terhadap dirinya; (3) confidence (percaya diri) ketekunan menghadapi tugas, 2) keuletan yaitu perasaan mampu karena memiliki potensi menghadapi kesulitan 3) menunjukkan minat untuk melakukan tugas sebagai syarat belajar, 4) keinginan bekerja mandiri, 5) mencapai keberhasilan; dan (4) satisfaction ketekunan menyelesaikan -tugas yang rutin,6) (kepuasan) yaitu usaha belajar sampai mempertahankan pendapat, 7) berhasil.

mempertahankan hal yang diyakininya 8) senang mencari dan memecahkan masalah/ soal, (9) tidak mau menyerah tanpa berusaha, (10) sikap segera puas dengan apa yang telah dikuasai atau dipahami, dan (11) selalu senang berhadapan dengan masalah yang berkaitan dengan materi kuliah.

Pembelajaran pada kelas regular akan lebih dinamis, lebih produktif, lebih komitmen dengan segala kesepakatan, lebih tinggi tingkat kinerjanya, lebih merasakan kepuasan secara psikologis dibandingkan pada kelas ekstensi. Konsekuensinya dalam pembelajaran akan lebih tinggi intensitasnya seperti rumusan Suciati (2001) dalam kutipan Melfaetty (2011) berkata : motivasi belajar yang diekspresikan dalam perilaku belajar memiliki empat komponen, yakni: keberhasilan mencapai tujuan belajar sebagai akibat adanya kepuasan atas harapan lebih tinggi intensitasnya pada kelas regular dibandingkan kelas ekstensi yakni: dalam hal (1) Perhatian (attention) yaitu perhatian siswa terhadap pelajaran karena
Perbedaan intensitas pembelajaran dan motivasi belajar tersebut diatas, adalah sesuatu yang logis dan wajar, bila dikembalikan ke belakang tentang proses penerimaan mahasiswa di UNIMED. Pada nyatanya mahasiswa regular adalah kelompok mahasiswa yang diterima dengan lulus seleksi melalui uji nasional dengan alat ukur teruji dan setara dengan skala kriteria tingkat nasional. Pada umumnya mahasiswa ekstensi adalah calon mahasiswa yang gagal atau tidak dapat mencapai target skala nasional yang telah ditetapkan. Sehingga proses penerimaan mahasiswa ekstensi ditentukan berdasarkan seleksi tingkat local yang mana instrumen yang digunakan masih mengikuti skala local, persaingan mereka masih mengikuti skala lokal. Oleh sebab itu, hal yang tidak bisa dimanipulasi, bahwa kemampuan, potensi, kesiapan, minat dan kebutuhan mahasiswa ekstensi secara psikologis dan secara sosioemosional menunjukkan kadar yang lebih rendah dibandingkan mahasiswa reguler dalam 
mengikuti perkuliahan yang dilakukan. Sardiman. (2011). Interaksi \& motivasi belajar Manifestasinya tampak dalam perilaku belajar sebagai wujud motivasi belajar yang mereka miliki. Dengan kata lain, potensi yang mengacu pada peningkatan motivasi belajar mahasiswa regular cenderung berbeda dengan lebih tinggi dibandingkan dengan mahasiswa ekstensi.

\section{SIMPULAN}

Implementasi pembelajaran ARIAS dalam tipe kolaboratif tersebut lebih tinggi intensitasnya di kelas Reguler dibandingkan dengan kelas ekstensi motivasi belajar. Sehingga peningkatan motivasi belajar mahasiswa regular lebih tinggi dibandingkan dengan peningkatan motivasi belajar mahasiswa kelas ekstensi. Perbedaan tersebut diprediksi akibat kemampuan atau potensi mahasiswa regular adalah lebih tinggi dibandingkan potensi / kemampuan mahasiswa ekstensi.

\section{REFERENSI}

Hamalik, O. (2008). Kurikulum dan pembelajaran. Bumi Aksara: Jakarta.

Huda, M. (2014). Model-model pengajaran dan pembelajaran. Pustaka Pelajar: Yogyakarta.

Dimyati, dkk (2002). Belajar dan pembelajaran. Rineka Cipta: Jakarta.

Purwanto, M. N. (1996). Psikologi pendidikan. Remaja Rosdakarya: Bandung.

Syah, M. (2004). Psikologi belajar. Raja Grafindo Persada: Jakarta.

Sagala, S. (2003). Konsep dan makna pembelajaran untuk membantu memecahkan problematika belajar dan mengajar. Alfabeta: Bandung.

Soemanto, W. (1983). Psikologi pendidikan. Rineka Cipta: Malang.

Saw, M. (1979). Group dynamics: The psychology of small group behavior. Mc Graw Hill: New Delhi.

Syarif, K. dkk. (2016) Perkembangan peserta didik: Bahan Kuliah MKDK UNIMED. University Press: Medan. 